\title{
Regeneration of the Catalysts by Supercritical Fluid Extraction
}

\author{
Farid M. Gumerov1, Ayrat A. Sagdeev², Rustam F. Gallyamov², Albina T. Galimova², \\ Kamil A. Sagdeev ${ }^{2}$ \\ ${ }^{1}$ Federal State Budgetary Educational Institution of Higher Professional Education "Kazan National Research \\ Technological University", Kazan, Russia \\ ${ }^{2}$ Nizhnekamsk Chemical Technological Institute (Branch Institute) of the Kazan National Research Technological \\ University, Nizhnekamsk, Russia \\ Email: gum@kstu.ru
}

Received 8 January 2014; revised 3 February 2014; accepted 7 March 2014

Copyright @ 2014 by authors and Scientific Research Publishing Inc.

This work is licensed under the Creative Commons Attribution International License (CC BY).

http://creativecommons.org/licenses/by/4.0/

(c) (i) Open Access

\section{Abstract}

The decontaminating of catalysts nickel on kieselguhr, activated aluminum oxide and palladium catalyst LD-265 agent's nature was analyzed. The possibility of catalyst's regeneration was examined using supercritical $\mathrm{CO}_{2}$ extraction. Regeneration of coked catalysts was carried out at $70^{\circ} \mathrm{C}$ and $150^{\circ} \mathrm{C}$ in the pressure range $10-30 \mathrm{MPa}$ by pure and modified supercritical $\mathrm{CO}_{2}$. Methanol and dimethylsulfoxide were used as modifiers (co-solvents) of supercritical $\mathrm{CO}_{2}$. The kinetics of supercritical $\mathrm{CO}_{2}$ regeneration process was studied. The activity of regenerated catalysts was measured.

\section{Keywords}

Nickel on Kieselguhr Catalyst; Activated Aluminum Oxide; Palladium Catalyst LD-265; Supercritical Carbon Dioxide; Regeneration

\section{Introduction}

Catalysts are one of the most high-tech and fast enough renewable products. Catalysts efficiency and the duration of their work determine the level of chemical technologies. Often due to the lack of effective methods of catalyst regeneration, many of these products are destroyed after a single use. Therefore, catalyst regeneration is one of the main problems in providing technical and economic efficiency of the vast majority of oil refining and petrochemical processes.

At chemical plants, the coke deposited on catalysts is traditionally removed by oxidative regeneration, which consists in the controlled burnout of coke by gaseous mixtures containing oxidizers (oxygen) at catalysis tem- 
perature or higher. However, the regeneration with an oxygen containing gas or thermal treatment with direct steam are multistage, time and energy consuming processes.

In our opinion, one promising method for regenerating catalysts is a supercritical fluid extraction (SCFE). The supercritical fluid (SCF) technology has significant advantages over traditional methods. In this case, the working media in the supercritical fluid state uniquely combines solubility, traditionally inherent in liquid organic solvents, as well as the low viscosity and high diffusion characteristic of gaseous media. The latest provides high mass transfer characteristics of the processes involving supercritical fluids [1].

Despite the fact that as the SCF solvent and extractant used wide range of compounds in a supercritical fluid state, nevertheless the supercritical carbon dioxide $\left(\mathrm{SC} \mathrm{CO}_{2}\right)$ is the most popular and widely demanded. This is because $\mathrm{CO}_{2}$ has a convenient critical parameters $\left(\mathrm{T}_{\mathrm{c}}=304.14 \mathrm{~K}, \mathrm{P}_{\mathrm{c}}=7.378 \mathrm{MPa}\right)$, it is inert, nonflammable and nonexplosive, as well as eco-friendliness of the obtained product and the production as a whole.

Regeneration process of catalysts and adsorbents using supercritical fluids in comparison with the traditional approach is milder conditions of the process, high efficiency and lower energy costs. Consequently catalysts under the new approach pass through more regeneration cycles. The scientific literature shows the interest to this process both the researchers [2]-[4], and the industrial implementations of this SCF method [5] [6].

The aim of the present work is to explore the possibility of regeneration of spent catalyst from the enterprise of "Nizhnekamskneftekhim" (nickel on kieselguhr, activated aluminium oxide, palladium catalyst LD-265) in a supercritical carbon dioxide medium.

\section{Experimental}

The experimental unit, which allows to studying the supercritical fluid extraction process with the use of both pure and modified extractant for the catalyst regeneration schematically shown in Figure 1.

The unit contains a high pressure plunger pump "Waters P50A", which provides a constant flow rate of solvent in supercritical state within 1 to $50 \mathrm{~g} / \mathrm{min}$ at a pressure of $60 \mathrm{MPa}$. To ensure the normal operation of the pump, it is necessary to supply liquid carbon dioxide $\left(\mathrm{CO}_{2}\right)$ into its inlet circuit. The gas is liquefied in the condenser and immediately in the pump with a refrigerant circulating in the cooling jacket of the pump and in the shell side of the condenser. The temperature to which the refrigerant $\left(-15^{\circ} \mathrm{C}\right)$ is cooled by the refrigerating unit is controlled by a chromel-copel thermocouple positioned in the condenser.

The co-solvent is fed by a LIQUPUMP 312/1 high pressure plunger pump from the vessel. The pump makes

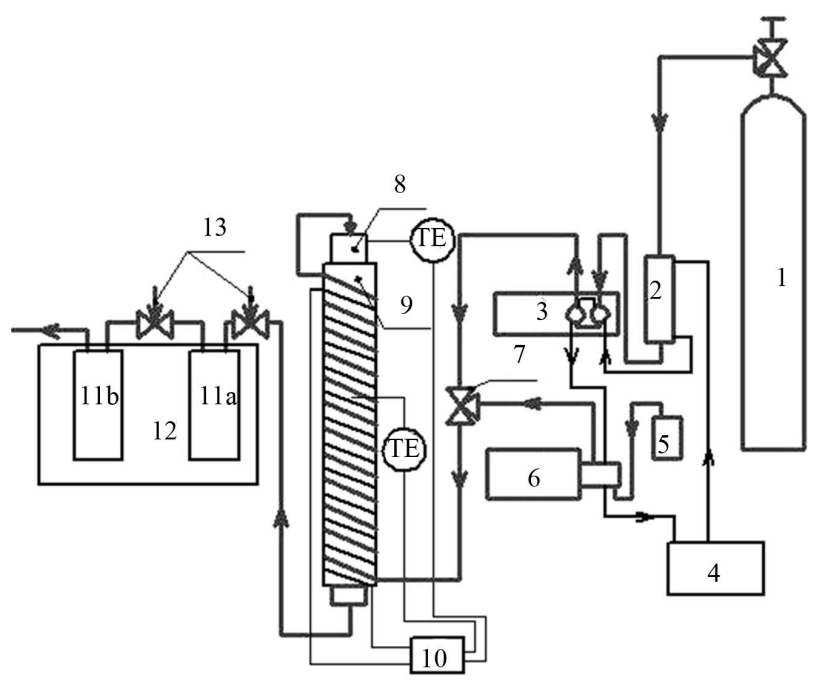

Figure 1. Scheme of the experimental unit: (1) $\mathrm{CO}_{2}$ gas bottle, (2) condenser; (3) high pressure pump "Water P50A"; (4) refrigerating unit; (5) vessel for co-solvent; (6) high pressure pump "LIQUPUMP 312/1"; (7) three way valve; (8) extraction cell; (9) heat exchanger; (10) electronic measuring controlling device 2TRM1; (11a,11b) extract collectors; (12) thermostatic bath; (13) throttle valve. 
it possible to regulate the co-solvent flow rate within $0.01-9.99 \mathrm{ml} / \mathrm{min}$ and thereby provides the required con-

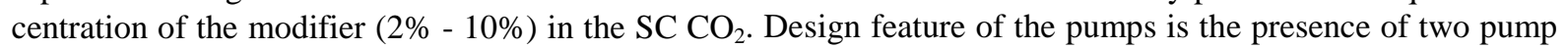
heads. The plungers in a heads, operates in successively mode due to which the solvent and co-solvent flow fluctuation is dampened and a high degree of uniformity feeding of solvent and co-solvent is provided [7]. To prevent $\mathrm{CO}_{2}$ and co-solvent returning into the pumps, check valves are used.

The extraction cell is a high pressure vessel divided into two parts: one part for extraction of solids, another part - the extraction of liquids. The cell is installed in a heat exchanger which is a thick walled copper tube equipped with the heating cable and pipe where the preheating of the solvent for extraction takes place. Such design provides for the maximum decrease of temperature gradients inside the cell due to uniform heating of the cell itself and preheating of the solvent. The cell is equipped with two temperature transmitters, one of which is installed directly on the cell body and the other one is on the heat exchanger. Transmitters signals are sent to the electronic measuring controlling device 2TRM1 maintaining the temperature with $\pm 0.25^{\circ} \mathrm{C}$ accuracy. Exchanger surface is covered with thermal insulation.

Collectors of extract represent the high pressure vessels, inside of which the interchangeable sleeves for extracts are located. Collectors are placed in a thermostatic bath. Throttle valves that act as the restrictor allows to fractionate the mixture by pressure changes.

The amount of coke deposit was determined by integral thermal analysis - thermogravimetry, derivative thermogravimetry in combination with differential thermal analysis (TG-DTA) on a "F.PAULIK" derivatograph (MOM, Hungary) within the temperature range from 293 - $1123 \mathrm{~K}$; analysis was performed in air using $600 \mathrm{mg}$ samples placed into open plate type platinum holders. The absolute measurement error of the temperature is \pm 5 $\mathrm{K}$, whereas the relative error in measuring the mass at a set sensitivity of $0.2 \mathrm{mg}$ is $\pm 0.5 \%$.

The qualitative analysis of the deactivated catalysts contaminating compounds was performed using the IR spectroscopy study. A $10 \mathrm{~g}$ catalyst sample was flooded with $25 \mathrm{ml}$ of chloroform. After $2 \mathrm{~h}$, the extract obtained was applied onto a $\mathrm{NaCl}$ plate and evaporated to obtain a thin film of the substance to be analyzed. The plate was placed into a Vector 33 FTIR spectrophotometer equipped with an attenuated total reflection device, and spectra within $600+4000 \mathrm{~cm}^{-1}$ were recorded at room temperature for $1 \mathrm{~min}$.

To quantitatively analyze the deactivating components, they were extracted in a Soxhlet extractor as described in [4]: the catalyst weight, $5 \mathrm{~g}$; extractant (acetone) volume, $20 \mathrm{ml}$; and extraction time, $1 \mathrm{~h}$. The concentrations of the extract components were determined by gas-liquid chromatography on a Kristall Lyuks 4000 instrument equipped with a flame ionization detector. The conditions of the analysis are as follows: carrier gas (hydrogen) flow rate, $1 \mathrm{ml} / \mathrm{min}$; heating rate, $10^{\circ} \mathrm{C} / \mathrm{min}$ (within the temperature range from $40^{\circ} \mathrm{C}$ to $200^{\circ} \mathrm{C}$ ); capillary column length, $50 \mathrm{~m}$; capillary diameter, $0.32 \mathrm{~mm}$; and stationary phase (polyethyleneglycol) thickness, $1.2 \mu \mathrm{m}$. The components were identified using a DSQ chromatomass spectrometer (Thermo Electron Corporation, USA) and the Xcalibur 1.4 software under the conditions identical to those used for the chromatographic analysis (column length, $50 \mathrm{~m}$; capillary diameter, $0.32 \mathrm{~mm}$ ).

\section{Results and Discussion}

\subsection{Regeneration of a Nickel on Kieselguhr Catalyst}

Catalysts nickel on kieselguhr is used for hydrogenation of unsaturated hydrocarbons more specifically for purifying isoprene from acetylene compounds. Table 1 lists the physicochemical characteristics of the nickel on kieselguhr catalyst that is used at the Nizhnekamskneftekhim plant.

The data of TG-DTA thermal analysis are displayed in Figure 2 and in Table 2. When a coked catalyst sample was heated, its weight gradually decreased, being accompanied by one endothermic and two exothermic effects. The endothermic effect $\left(100^{\circ} \mathrm{C}-120^{\circ} \mathrm{C}\right)$ is associated with the release of weakly bound water and low boiling hydrocarbons. The exothermic effects (peaks at $240^{\circ} \mathrm{C}$ and $800^{\circ} \mathrm{C}$ ) are indicative of oxidative processes. The existence of two effects suggests that the composition of the deposits is nonuniform. The maximum mass loss of the deactivated catalyst was observed at temperatures within $130^{\circ} \mathrm{C}-600^{\circ} \mathrm{C}$ and $700^{\circ} \mathrm{C}-850^{\circ} \mathrm{C}$, with the total content of densification products reaching 22.4\% [3].

An analysis of the IR spectra (Figure 3) of the worked out catalyst shows that the coke deposits are largely composed of reaction products, more specifically, oligomers of isoprene, cis- and trans-isoamylenes, and oxidation products. The bands observed in the spectra were assigned to the following functional groups: RR' $\mathrm{C}=$ $\mathrm{CH} 2\left(890 \mathrm{~cm}^{-1}\right.$, bending vibrations); CHR = CHR1 $\left(965 \mathrm{~cm}^{-1}\right.$, bending vibrations); CO $\left(1709 \mathrm{~cm}^{-1}\right.$, stretching 
Table 1. Physicochemical characteristics of the catalyst.

\begin{tabular}{cc}
\hline Mass fraction of nickel, wt\%, not higher than & 54 \\
Mass fraction of sulfide sulfur, wt\%, not higher than & 0.38 \\
$\begin{array}{c}\text { Activity (according to technical specifications) as determined } \\
\text { in the hydrogenation of pseudocumene, \%, not less than }\end{array}$ & 65 \\
Selectivity determined in the hydrogenation of acetylene, \%, not less than & 73 \\
Bulk density, g/ $\mathrm{cm}^{3}$, not less than & 1.15 \\
Crushing force applied to the element of cylinder, & 8.0 \\
kg/tablet average, not less than minimum, not less than & 5.0 \\
\hline
\end{tabular}

Table 2. IR spectroscopy and TG-DTA analysis data for the deactivated catalyst.

\begin{tabular}{ccc}
\hline Temperature, ${ }^{\circ} \mathrm{C}$ & Name & Mass fraction, \% \\
\hline$<200$ & Volatile components & 5.8 \\
$200-340$ & Alkylbenzenes & 5.8 \\
$340-600$ & Oxidized oligomers & 5.0 \\
$600-720$ & Semicoke & 0.8 \\
$720-850$ & Middle temperature coke & 3.3 \\
$>850$ & High temperature coke & 1.7 \\
\hline
\end{tabular}

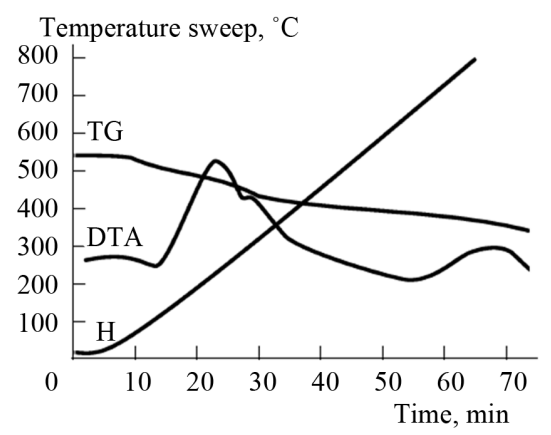

Figure 2. TG-DTA curves for the deactivated nickel on kieselguhr catalyst.

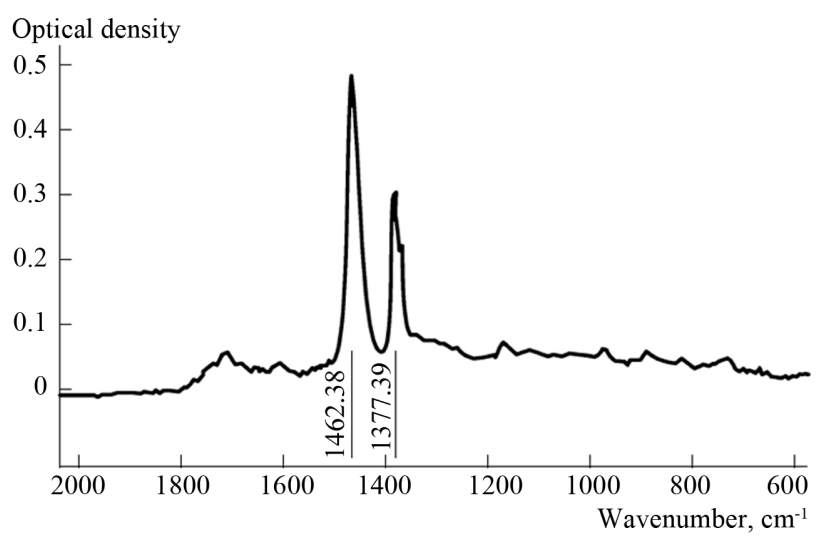

Figure 3. IR spectrum of the deposit on the nickel on kieselguhr catalyst. 
vibrations); and C-O (1166 $\mathrm{cm}^{-1}$, stretching vibrations).

The data on the composition of the densification products obtained by chromatography and chromate mass spectroscopy are presented in Table 3.

An analysis of the results led us to conclude that the largest amount of compounds deactivating the catalysts falls at isoprene oligomers. This suggests that the coke precursors are components of the reaction mixture and their hydration products. In the course of catalyst operation, active sites are blocked. The formation of deposits can also result in a decrease in the diffusion rate of the reaction mixture components in the catalyst granules. All these changes can occur during hydrogenation of acetylene compounds [3].

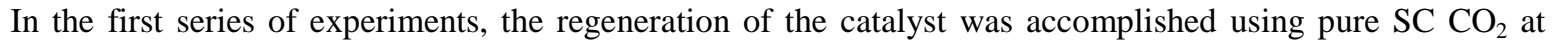
temperatures of $70^{\circ} \mathrm{C}$ and $150^{\circ} \mathrm{C}$ and pressures of 10,20 , and $30 \mathrm{MPa}$ (Figure 4). The process was accompanied by a decrease in the catalyst mass (up to 3.4\%), indicative of the principle possibility of removing deposits by using the proposed method. An evengreater effect can be achieved by increasing the mass of carbon dioxide used, adjusting the parameters of the process, and modifying the extractant (by introducing a polar additive).

The IR spectra of the regenerated catalyst samples (Figure 5) confirm the occurrence of changes, primarily a decrease in the amount of deactivating compounds. The most important spectral range for this catalyst is 1800 $1200 \mathrm{~cm}^{-1}$, where bands belonging to the compounds most strongly decreasing the catalytic activity lie. As can be seen from Figure 5, compounds with absorption bands near $1500 \mathrm{~cm}^{-1}$ are removed most effectively.

This suggests that the absorption bands at 1600 and $1380 \mathrm{~cm}^{-1}$ can be assigned to polar compounds or inorganic compounds, which are only slightly dissolved in and, hence, poorly removed by pure $\mathrm{SC} \mathrm{CO}_{2}$.

The dissolution ability of non-polar carbon dioxide with respect to polar substances can be substantially increased by adding polar co-solvents. Given that the interaction between co-solvent and solute molecules is of specific nature, the selectivity of the process of extraction often increases. Pure $\mathrm{SC} \mathrm{CO}_{2}$ only slightly dissolves polar compounds, but its dissolution ability increases sharply upon addition of a co-solvent.

Table 3. Chromatomass spectrometry data.

\begin{tabular}{|c|c|}
\hline Name & Mass fraction, \% \\
\hline \multicolumn{2}{|c|}{ Extract from the deactivated unregenerated catalyst } \\
\hline Hexane & 7.8 \\
\hline DMFA & 4.78 \\
\hline Toluene & 8.4 \\
\hline Isoprene oligomers $\left(\mathrm{C}_{11} \mathrm{H}_{22}-\mathrm{C}_{15} \mathrm{H}_{30}\right)$ & 55.4 \\
\hline Paraffins & $20-25$ \\
\hline \multicolumn{2}{|c|}{$\begin{array}{l}\text { Extract from the catalyst regenerated with a } 3 \% \text { wt } \\
\text { methanol-SC } \mathrm{CO}_{2} \text { mixture }\end{array}$} \\
\hline Hexane & 0.34 \\
\hline Toluene & 0.56 \\
\hline DMFA & 3.53 \\
\hline Methanol & 60.1 \\
\hline Hydrocarbons $\left(\mathrm{C}_{7} \mathrm{H}_{14}\right)$ & 32.6 \\
\hline \multicolumn{2}{|c|}{ Compounds extracted after the process of regeneration } \\
\hline Hexane & 0.17 \\
\hline Toluene & 0.8 \\
\hline DMFA & 0.593 \\
\hline Isoprene oligomers $\left(\mathrm{C}_{11} \mathrm{H}_{22}-\mathrm{C}_{20} \mathrm{H}_{42}\right)$ & 68.156 \\
\hline Paraffins & 29.82 \\
\hline
\end{tabular}




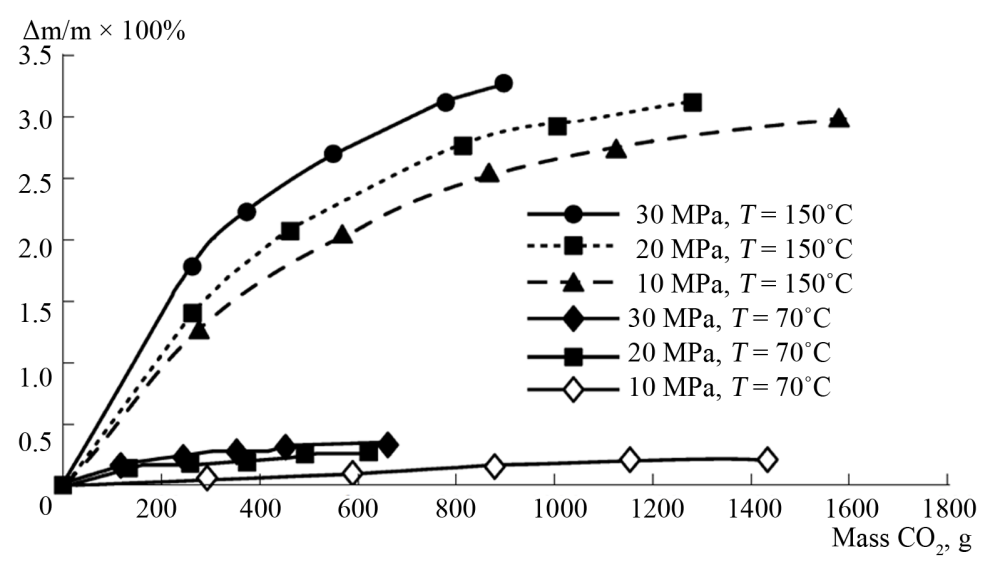

Figure 4. Change in the mass of the catalyst in the course of its regeneration versus the mass of extractant used (pure $\mathrm{CO}_{2}$ ).

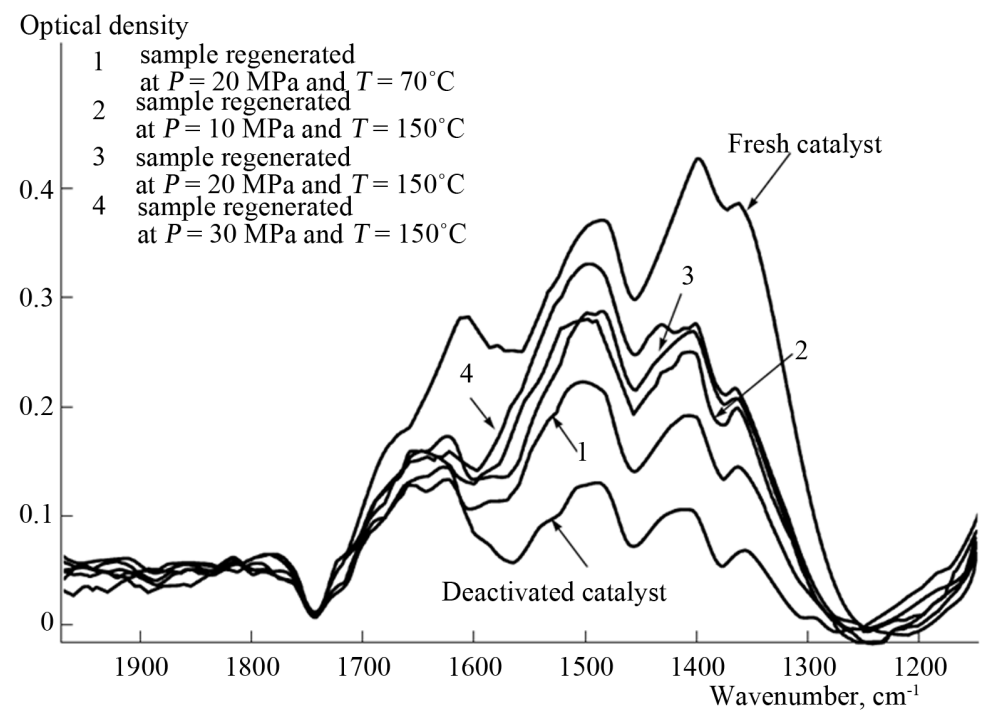

Figure 5. IR spectra of the deactivating compounds (coke) for various samples (fresh, worked out, regenerated at different regeneration parameters) of the test catalyst.

Modifiers, such as methanol, ethanol, etc., in amounts of $0.1 \mathrm{wt} \%$ to $20 \mathrm{wt} \%$ can be added either before introducing the extractant into the extractor or immediately in the extractor. The results of studying the regeneration of the catalyst in a $3 \mathrm{wt} \%$ methanol-SC $\mathrm{CO}_{2}$ are displayed in Figure 6. These data show that the efficiency of regeneration increases markedly with the pressure and temperature, but the most important factor being the methanol additive.

As can be seen from Figure 7, regeneration with modified $\mathrm{SC} \mathrm{CO}_{2}$ makes it possible to remove polar compounds more efficiently as compared to pure $\mathrm{SC} \mathrm{CO}_{2}$, as can be judged from a decrease in the intensity of the 1600 and $1400 \mathrm{~cm}^{-1}$ absorption bands. Thus, the modification of SC $\mathrm{CO}_{2}$ by adding a polar co-solvent allows the removal of polar compounds entering into the composition of coke. To achieve the best result, it is necessary to select an optimal polar co-solvent and its optimal concentration.

The catalysts were tested in a pulse microcatalytic setup. This setup was used for both pretreating the catalyst (reduction with hydrogen) and testing its activity. The activity of the catalyst was estimated from the extent of hydrogenation of ethylene to ethane as a $50 \%$ ethylene $+50 \%$ hydrogen mixture was introduced in pulses into the carrier gas flow upstream of the microreactor.

Four catalysts were tested: initial (freshly prepared), worked out, and two regenerated with the SC carbon dioxide. One sample was regenerated with pure $\mathrm{SC} \mathrm{CO}_{2}$, another one with a $3 \mathrm{wt} \%$ methanol-SC $\mathrm{CO}_{2}$ mixture. 


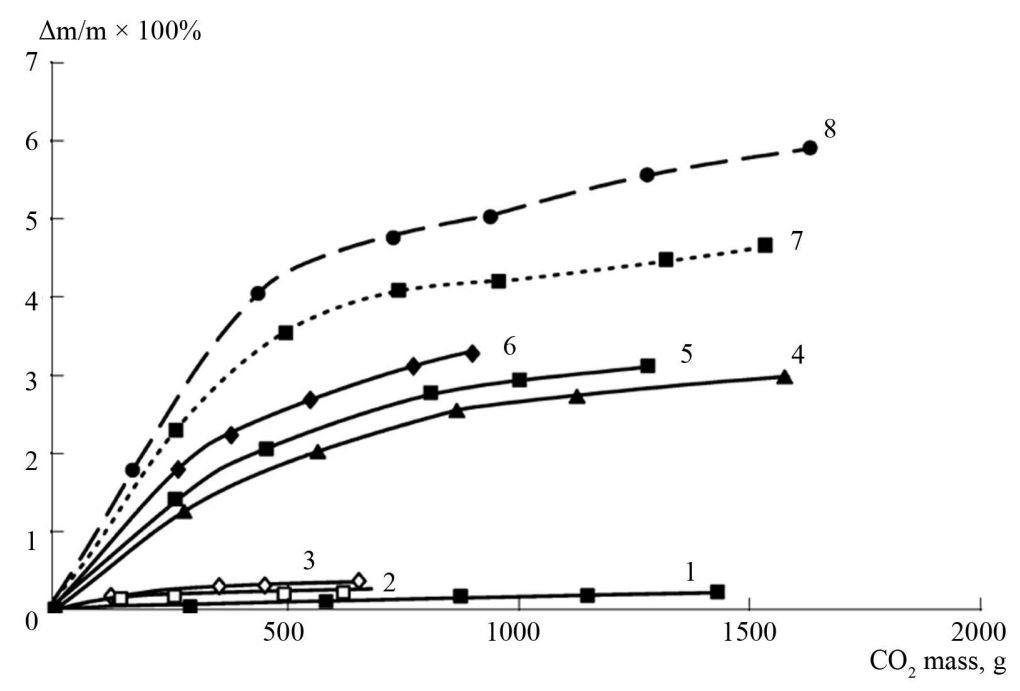

Figure 6. Change in the mass of the catalyst in the course of its regeneration versus the mount of extractant used: $(1-6) \mathrm{SC} \mathrm{CO}_{2}$ and $(7,8) \mathrm{SC} \mathrm{CO}_{2}+3 \mathrm{wt} \%$ methanol; $(1-3,7,8) 70^{\circ} \mathrm{C}$ and $(4-6) 150^{\circ} \mathrm{C}$; $(1,4) 10 \mathrm{MPa},(2,5,8) 20 \mathrm{MPa}$, $(3,6) 30 \mathrm{MPa}$, and (7) $15 \mathrm{MPa}$.

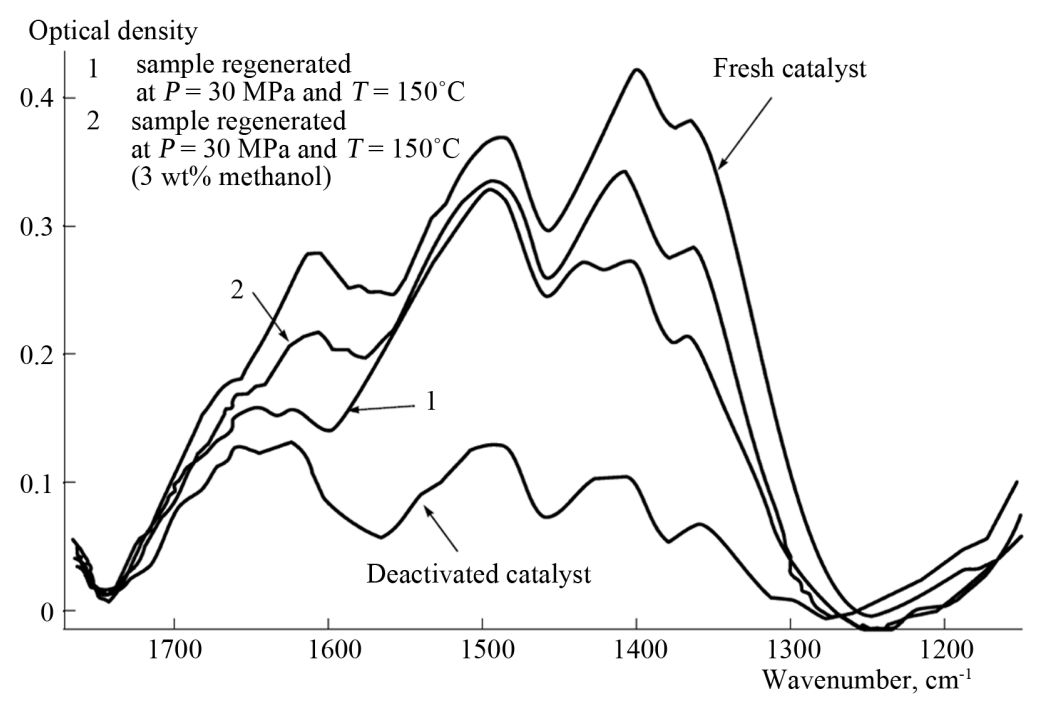

Figure 7. IR spectra of the deactivating compounds of catalyst samples regenerated in pure and modified $\mathrm{SC} \mathrm{CO}_{2}$.

The results are summarized in Table 4. As can be seen, the catalytic properties of a sample deactivated under real conditions are completely recovered after treatment in a medium of both pure and methanol modified SC $\mathrm{CO}_{2}$.

Activated aluminum oxide is used as a catalyst for the dehydration of methyl phenyl carbinol. Physical and chemical properties of the catalyst are specified in the Table 5 [8]:

During the dehydration reaction of methyl phenyl carbinol the carbon deposition occurs on the catalyst surface which reduces the catalyst activity.

After 400 - 600 hours of operation the catalyst is to be regenerated for the purpose of its reactivation. The catalyst regeneration is accomplished with vapour-air mixture at temperature of $400^{\circ} \mathrm{C}-600^{\circ} \mathrm{C}$. However the catalyst is not completely regenerated using this method as it is impossible to remove all coke; part of it unavoidably will remain on the catalyst. There is also a risk of catalyst sintering due to styrene polymer occurrence reducing the catalyst service life. 
Table 4. Activity of the catalyst samples subjected to various treatments in the hydrogenation of ethylene.

\begin{tabular}{|c|c|c|c|c|}
\hline \multirow{2}{*}{ Product } & \multicolumn{4}{|c|}{ Sample } \\
\hline & Initial & Worked out & Regenerated (SC $\mathrm{CO}_{2}+3 \%$ wt methanol) & Regenerated $\left(\mathrm{SC} \mathrm{CO}_{2}\right)$ \\
\hline Ethane, vol\% & 91.5 & 87.7 & 92.3 & 92.9 \\
\hline Ethylene, vol\% & 8.5 & 12.3 & 7.7 & 7.1 \\
\hline
\end{tabular}

Table 5. Physical and chemical catalyst properties.

\begin{tabular}{cc}
\hline Description & Activated aluminum oxide \\
\hline 1. Shape & White cylindrical-shaped beads, ivory color is possible \\
2. Size, $\mathrm{mm}$ : diameter & $5.0 \pm 1.0$ \\
length, max & 18 \\
3. Bulk density, $\mathrm{g} / \mathrm{dm}^{3}$ & $450-550$ \\
4. Abrasion resistance, $\%$, min & 65.0 \\
5. Surface area, $\mathrm{m}^{2} / \mathrm{g}$ & Min 200 \\
\hline
\end{tabular}

The data of TG-DTA thermal analysis are displayed in Figure 8 and in Table 6. The maximum mass loss of the deactivated catalyst is observed at temperatures within $440^{\circ} \mathrm{C}-560^{\circ} \mathrm{C}$, with the total content of deposit reaching $9.7 \%$.

An analysis of the IR spectra (Figure 9) of the worked out catalyst shows that the coke deposits are largely composed of reaction products: oligomers of styrene, ether of methyl phenyl carbinol, styrene polymers and resins.

The results of the chromatographic analysis of the extract from the catalyst are in Table 7 [9].

Determination of the possibility of coked catalyst regeneration assumes the availability of solubility data for pure compounds, deactivating compounds in supercritical carbon dioxide. On this basis the studies were made for the solubility of such compounds in supercritical carbon dioxide, more specifically styrene, methyl phenyl carbinol, acetophenone [9] [10]. The results show the satisfactory solubility of pure compounds in supercritical $\mathrm{CO}_{2}$.

Activated aluminum oxide catalyst was regenerated at temperature of $423 \mathrm{~K}$ and within the pressure range 10 - 30 $\mathrm{MPa}$. The results of the analysis are as follows (Figure 10).

The determined decrease of catalyst mass (Figure 10) confirms that deactivating compounds were effectively removed.

The IR spectra of the regenerated catalyst samples (Figure 11) confirm the decrease in the amount of deactivating compounds in matrix.

As it was mentioned above, if modifiers $0.1 \mathrm{wt} \%$ - $20 \mathrm{wt} \%$ such as methanol, ethanol etc. are added the dissolution ability of $\mathrm{SC} \mathrm{CO}_{2}$ is increased. On this basis the impact of various co-solvents on the catalyst mass during the regeneration was studied. Chloroform, methanol, acetone and dimethylsulfoxide (DMSO) were chosen as co-solvents. Co-solvents concentration varied from 1 to $9 \mathrm{wt} \%$. Figure 12 represents the results of impact study of various co-solvents on the catalyst mass during the regeneration at temperature $T=343 \mathrm{~K}$ and pressure $P=20 \mathrm{MPa}$. With the increase of co-solvent concentration the change of the catalyst mass grows in the beginning then passes through the maximum point and after that decreases. The optimum value of co-solvent concentration falls within the range of $1.5 \%-2.5 \%$.

The analysis of catalyst mass change in the course of its regeneration using the modified SC carbon dioxide with the optimum co-solvent concentration was made at the temperature of $T=423 \mathrm{~K}$ and pressure $\mathrm{P}=20 \mathrm{MPa}$ (Figure 13). It is seen from the diagram that the regeneration efficiency with the DMSO adding has increased by $120 \%$ due to polar compounds removal. This data is supported by the IR spectra of the deactivating compounds for catalysts samples regenerated with pure and modified $\mathrm{SC} \mathrm{CO}_{2}$ (Figure 14).

Furthermore within the scope of this study the measurement of the regenerated catalyst selectivity and conversion was made on the unit for the methyl phenyl carbinol vapor-phase dehydration process research. 
Table 6. IR spectroscopy and TG-DTG analysis data for the deactivated catalyst.

\begin{tabular}{ccc}
\hline Temperature, ${ }^{\circ} \mathrm{C}$ & Description & Mass fraction, \% \\
\hline$<120$ & Volatile compounds & 1.9 \\
$300-440$ & Styrene polymer & 1.6 \\
$440-560$ & Resins & 4.8 \\
$560-850$ & Olygomers & 1.4 \\
\hline
\end{tabular}

Table 7. Composition of the compounds deactivating the catalyst.

\begin{tabular}{cc}
\hline Description & Content, wt \% \\
\hline styrene & 19.63 \\
methylstyrene & 16.44 \\
acetophenone & 6.54 \\
methyl phenyl carbinol & 28.22 \\
phenol & 16.89 \\
others & 12.28 \\
\hline
\end{tabular}

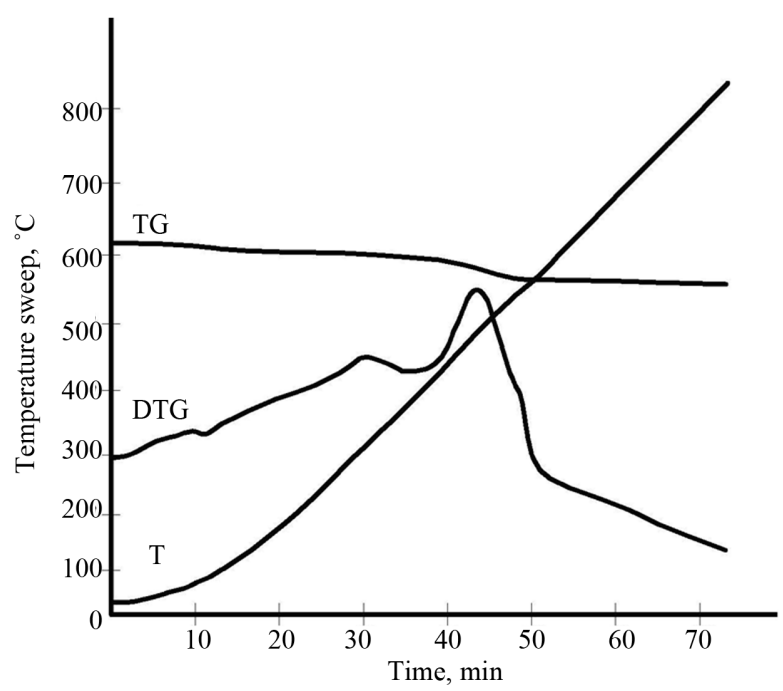

Figure 8. TG-DTG curves for the deactivated activated aluminum oxide catalyst.

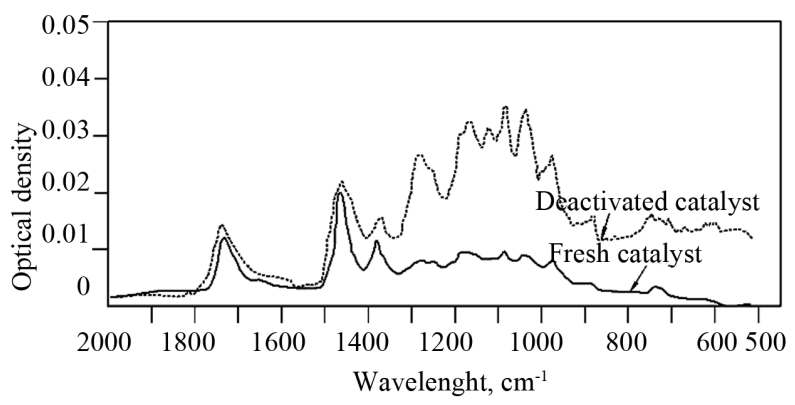

Figure 9. IR spectrum of the fresh and deactivated activated aluminum oxide catalyst. 


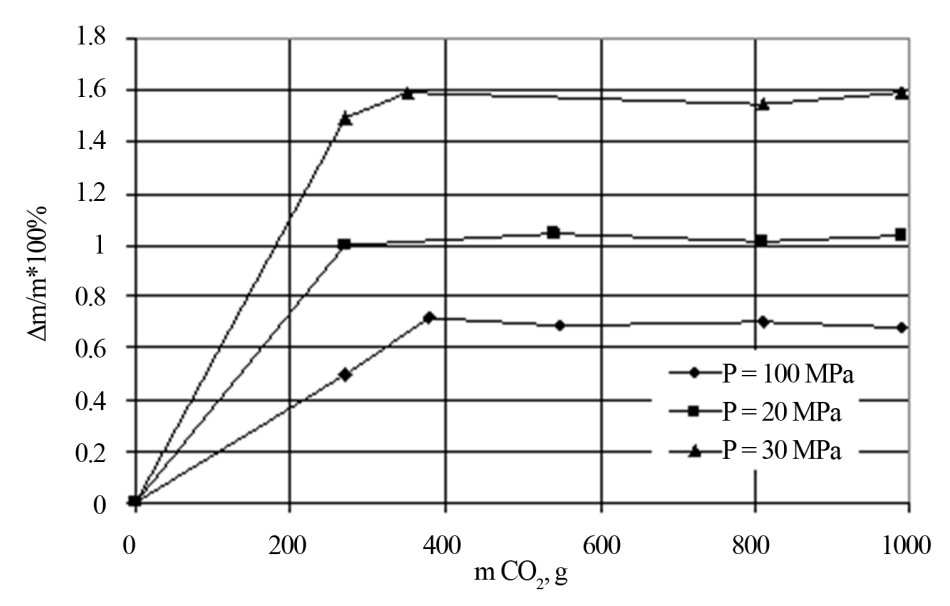

Figure 10. Change in the mass of the catalyst in the course of its regeneration versus the mass of extractant used (pure $\mathrm{CO}_{2}$ ) at $T=423 \mathrm{~K}$.

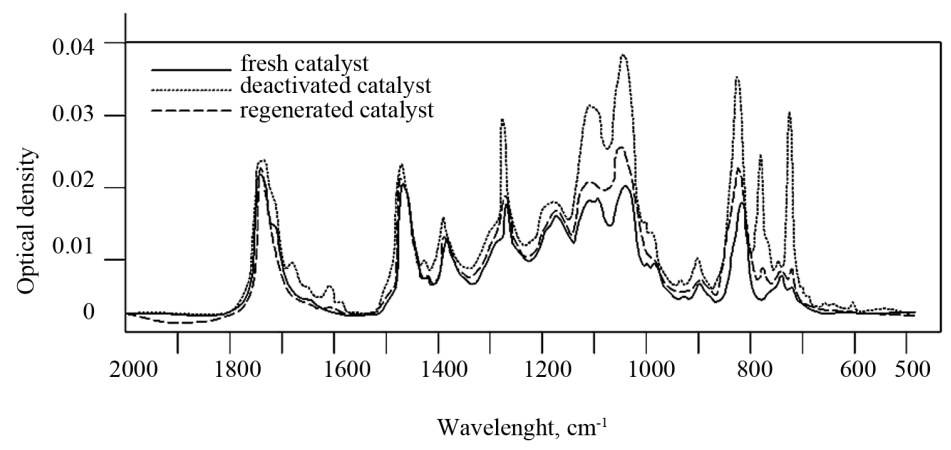

Figure 11. The IR spectra of the deactivating compounds for various samples of the analyzed catalyst.

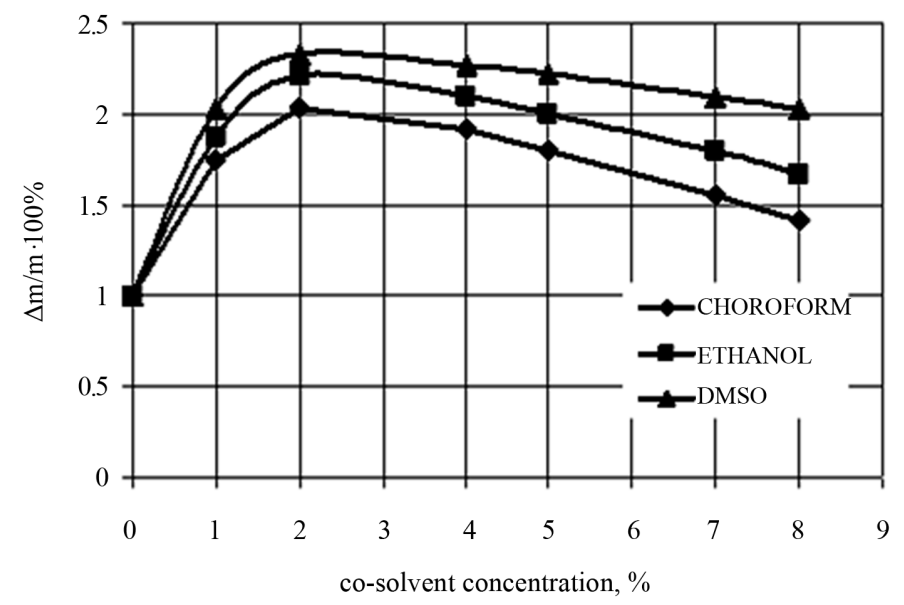

Figure 12. Change in the mass of the catalyst in the course of its regeneration at $T=343 \mathrm{~K}$ and $P=20 \mathrm{MPa}$ versus the concentration of various co-solvents.

It is known that the catalyst activity characterizes the change of reaction rate when the catalyst is fed to the reaction system. Energy of activation, degree of reactant conversion (conversion), reaction product output, reaction time and temperature during which the certain conversion degree is achieved are sometimes used as an activity degree of the catalyst. 


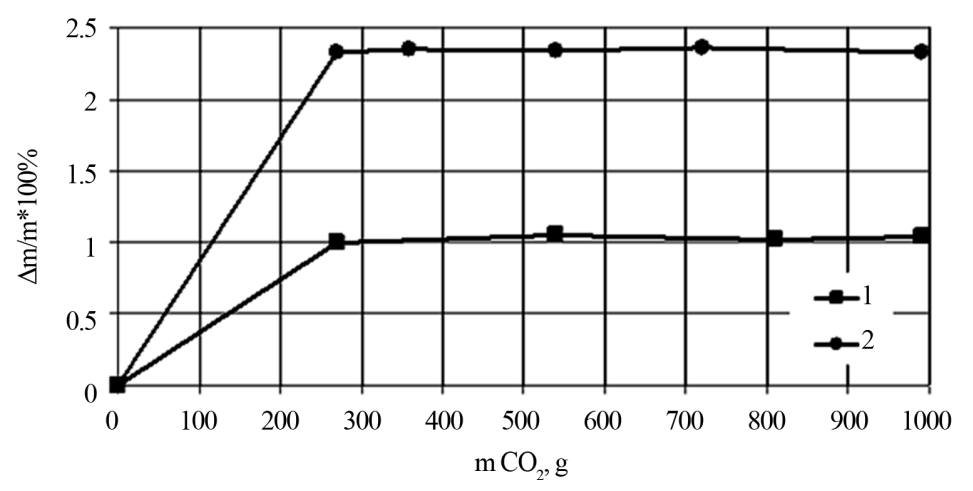

Figure 13. Change in the mass of the catalyst in the course of its regeneration versus the mass of extractant used (modified $\mathrm{CO}_{2}$ ): $1-\mathrm{SC} \mathrm{CO}_{2} ; 2-$ $\mathrm{SC} \mathrm{CO}_{2}+2 \%$ DMSO.

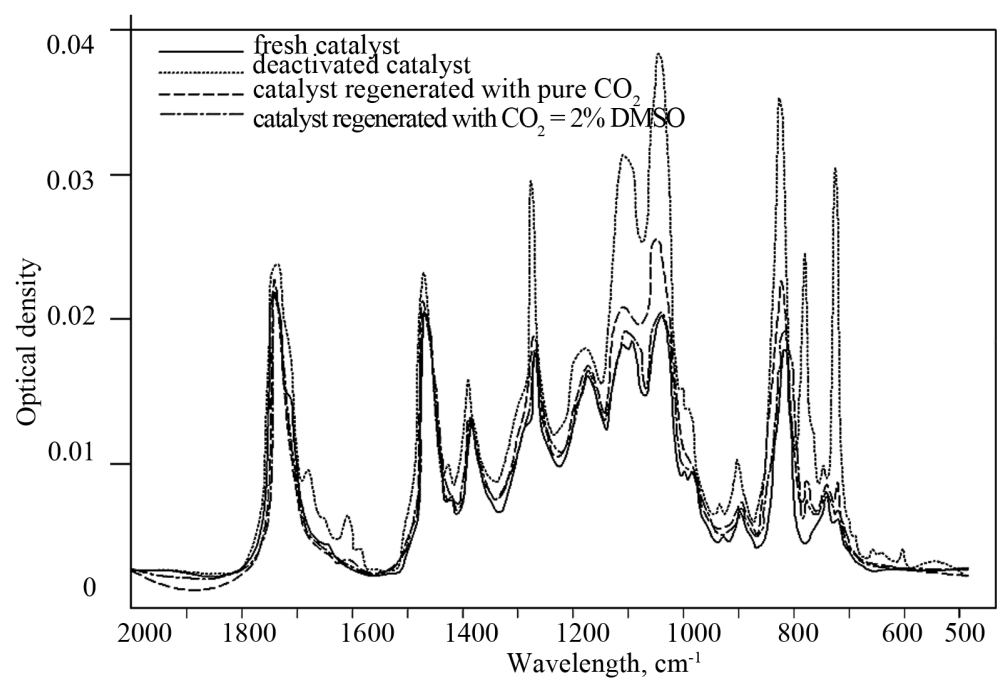

Figure 14. The IR spectra of the deactivating compounds for catalysts samples regenerated with pure and modified $\mathrm{SC} \mathrm{CO}_{2}$.

In this case the conversion rate of methyl phenyl carbinol (methyl phenyl carbinol conversion) and selectivity to styrene were the criteria for activated aluminum oxide catalyst activity evaluation.

Methyl phenyl carbinol (MPC) fraction consists of high boiling products the total amount of which is determined as a heavy residue. The heavy residue includes the compounds (methyl phenyl carbinol ether, phenylethanol) which can be converted into styrene or methyl phenyl carbinol during the reaction. Therefore the conversion of heavy residue was also estimated during the catalyst testing.

The results of methyl phenyl carbinol conversion and activated aluminum oxide catalyst selectivity analysis are in Table 8.

Regenerated catalyst MPC conversion value, i.e. the catalyst regenerated activity, proves the SCFE method efficiency for removal of contaminants from the surface of activated alumina.

\subsection{Regeneration of Palladium Catalyst LD-265}

Samples of spent cocked catalyst LD-265, pretreated with air-steam mixture were taken from Nizhnekamskneftekhim hydrogenation reactors as these catalysts were to be replaced due to the expiration of the catalyst life cycle.

Physical and chemical properties of LD-265 are given in Table 9.

Complete thermal analysis data (thermogravimetric and differencial thermogravimetric curves) are given in Figure 15 and Table 10. 
Table 8. MPC heavy residue conversion and styrene formation selectivity values.

\begin{tabular}{cccc}
\hline & $\begin{array}{c}\text { Fresh } \\
\text { catalyst }\end{array}$ & $\begin{array}{c}\text { Catalyst regenerated by } \\
\text { air-steam mixture }\end{array}$ & $\begin{array}{c}\text { Catalyst regenerated by } \\
\text { pure supercritical } \mathrm{CO}_{2}\end{array}$ \\
\hline MPC Conversion, \% & 99.80 & 99.69 & 99.77 \\
Heavy residue Conversion, \% & 75.01 & 69.85 & 70.44 \\
$\begin{array}{c}\text { Styrene Formation Selectivity (towards } \\
\text { decomposed MPC), \% mol. }\end{array}$ & 100 & 86.99 & 93.97 \\
$\begin{array}{c}\text { Styrene Formation Selectivity (towards } \\
\text { decomposed MPC and heavy residue), \% mol. }\end{array}$ & 103.9 & 90.70 & 97.69 \\
\hline
\end{tabular}

Table 9. LD-265 physical and chemical properties.

\begin{tabular}{cc}
\hline Appearance & Light-brown balls \\
\hline Particle Diameter, mm & $2-4$ \\
Palladium Content (Pd), \% wt. & 0.3 \\
Specific Surface, $\mathrm{m}^{2} / \mathrm{g}$ & 70.0 \\
Total Pore Volume, $\mathrm{cm}^{3} / \mathrm{g}$ & 0.6 \\
Bulk Density, $\mathrm{kg} / \mathrm{l}$ & 0.66 \\
Ball Crushing Strength, MPa, not less than & 1.55
\end{tabular}

Table 10. Catalyst samples weight loss detected by TG-DTG method.

\begin{tabular}{cc}
\hline \multicolumn{1}{c}{ Catalyst Sample Description } & $\begin{array}{c}\text { Catalyst Weight } \\
\text { Loss, } \%\end{array}$ \\
\hline \multicolumn{1}{c}{ Spent Catalyst } & 4.29 \\
Regenerated Catalyst at $t=70^{\circ} \mathrm{C}, P=10 \mathrm{MPa}$ & 3.74 \\
Regenerated Catalyst at $t=70^{\circ} \mathrm{C}, P=20 \mathrm{MPa}$ & 3.70 \\
Regenerated Catalyst at $t=150^{\circ} \mathrm{C}, P=10 \mathrm{MPa}$ & 3.11 \\
Regenerated Catalyst at $t=150^{\circ} \mathrm{C}, P=20 \mathrm{MPa}$ & 2.46 \\
\hline
\end{tabular}

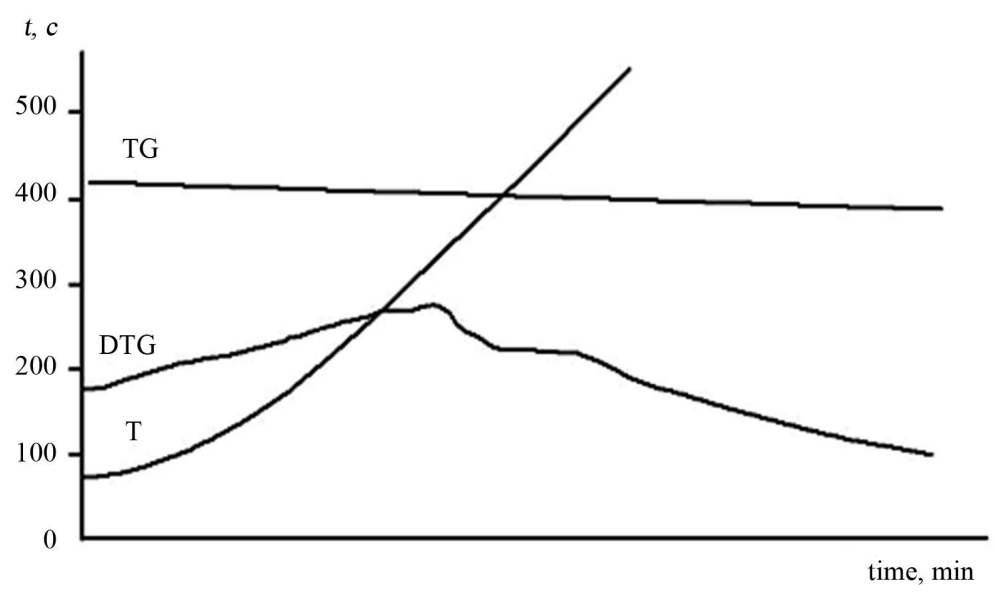

Figure 15. Thermogravimetric and differencial thermogravimetric curves of spent catalyst LD-265. 
Maximum weight loss of spent catalyst and, thus, the maximum thermal effect appears at $320^{\circ} \mathrm{C}$.

During the spent catalyst sample heating some weight loss occurs (4.29\%) accompanied by two exothermic effects with pick values at $320^{\circ} \mathrm{C}$ and $420^{\circ} \mathrm{C}$

The higher temperature of hydrocarbon deposits burnout at the second pick value indicates the presence of more highly condensed coke structures.

Regenerated catalyst sample heating using SCFE method is accompanied by slow weight loss with only one exothermic effect with a pick value at $420^{\circ} \mathrm{C}$. The fact that there is only one exothermic effect proves the removal of low boiling point contaminants.

Catalyst regeneration is performed at temperature of $70^{\circ} \mathrm{C}$ and $150^{\circ} \mathrm{C}$ and pressure of 10,20 and $30 \mathrm{MPa}$ with pure supercritical $\mathrm{CO}_{2}[11]$.

Temperature increase has a positive impact on Catalyst Regeneration Process as shown in Table 10 and Figure 16.

Catalyst Weight during Regeneration depending on Extraction Agent Weight (pure $\mathrm{CO}_{2}$ ).

Weight Loss of regenerated catalyst samples up to $2.46 \%$ proves the possibility of coke deposits removal.

Comparison of IR spectra of contaminating depositions derived from spent catalysts after regeneration with air-steam mixture and SCFE (Figure 17) demonstrates the change, in particular the reduced amount of contaminating depositions.

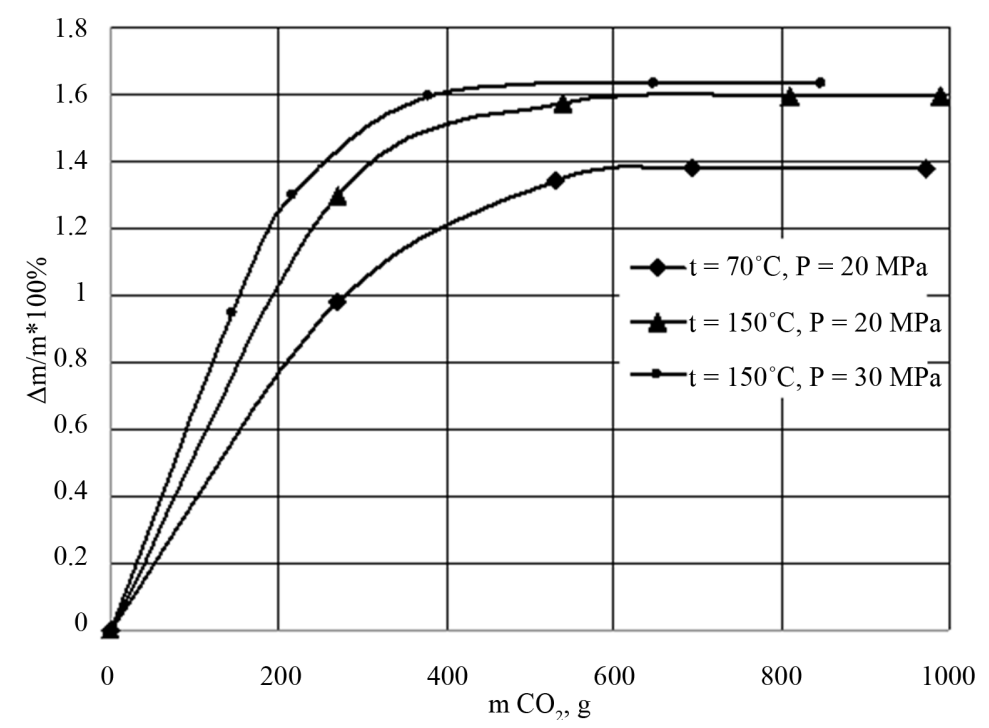

Figure 16. LD-265 catalyst weight history curve.

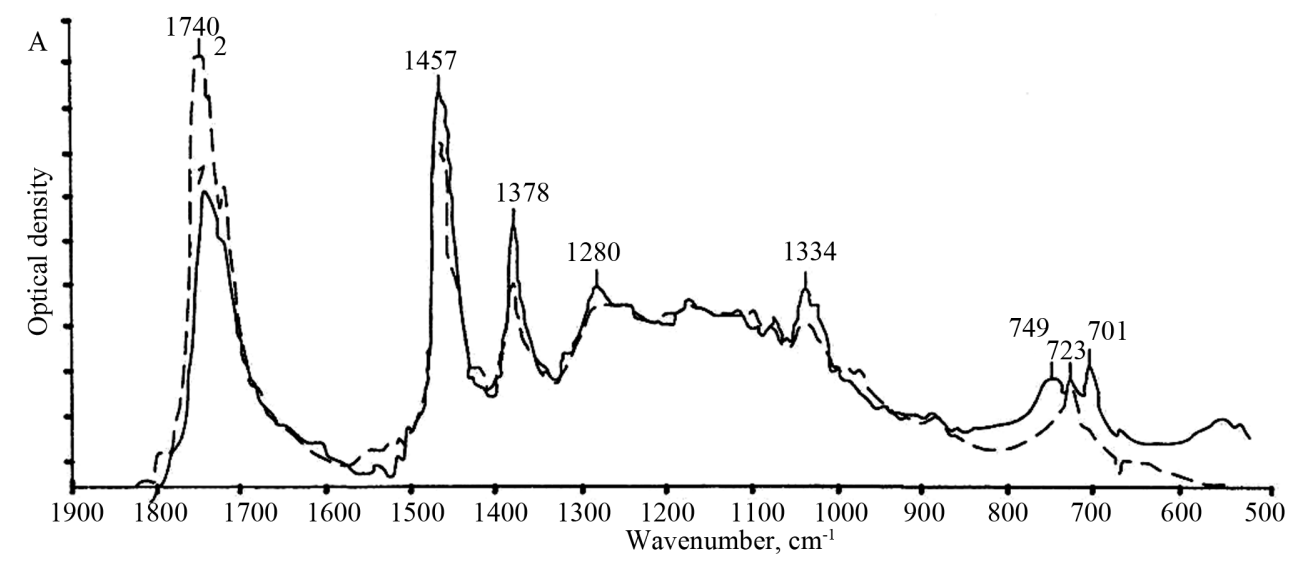

Figure 17. IR spectra of contaminating decompositions of LD-265: 1-sample regenerated by air-steam mixture; 2 -sample regenerated by SCFE Method at $t=150^{\circ} \mathrm{C}$ and $P=20 \mathrm{MPa}$. 
The observed increase of optical density of decompositions with carbonyl group at $1740 \mathrm{~cm}^{-1}$ can be attributable to $\mathrm{CO}_{2}$ integration into caulked products during regeneration process. Decreased optical density of $\dot{\alpha}, \beta$-unsaturated aliphatic acid ethers $\left(1280 \mathrm{~cm}^{-1}\right)$, organic sulphur compounds $\left(1034 \mathrm{~cm}^{-1}\right)$, alkylbenzene (701 and 749 $\mathrm{cm}^{-1}$ ) proves the reduction of actual amount of contaminating decompositions.

\section{Conclusions}

The results of complete thermal analysis and spent catalyst IR spectra prove the removal of contaminating decompositions from catalyst surface and support the possibility of application of SCFE Method for catalyst regeneration. The greater efficiency can be achieved by process parameters adjustment and extraction agent modification (in particular by adding some polar additive).

The regenerated catalyst activity proves the efficiency of SCFE process for removal of contaminating decompositions from catalyst surface.

Thus the Supercritical Fluid Extraction is one of the prospective methods of catalyst regeneration. The application of this method gives an option to solve the problems of traditional regeneration methods.

\section{References}

[1] Gumerov, F.M., Sabirzyanov, A.N. and Gumerova, G.I. (2000) Sub- and Supercritical Fluids in Polymer. Science, Kazan, 328 p.

[2] Bilalov, T.R., Gumerov, F.M., Gabitov, F.R., Fyodorov, G.I., Kharlampidi, K.E. and Sagdeev, A.A. (2009) Supercritical Carbon Dioxide Assisted Synthesis and Regeneration of Palladium Catalyst. Supercritical Fluids: Theory and Practice, 4, 34-52.

[3] Gallyamov, R.F., Sagdeev, A.A., Gumerov, F.M. and Gabitov, F.R. (2010) Regeneration of "Nickel on Kieselguhr” Catalyst Using Supercritical Carbon Dioxide. Supercritical Fluids: Theory and Practice, 5, 40-51.

[4] Bogdan, V.I., Koklin, A.E. and Kazansky, V.B. (2006) Regeneration of Deactivated Palladium Catalyst of Selective Acetylene Hydrogenation by Supercritical $\mathrm{CO}_{2}$. Supercritical Fluids: Theory and Practice, 1, 5-12.

[5] Cansell, F. and Petitet, J.-P. (1995) Fluides supercritiques et materiaux. LIMHP CNRS, Paris, 327 p.

[6] Johnston, K.P. (1989) New Direction in Supercritical Fluid Science and Technology. Journal of the American Chemical Society, 406, 1-12. http://dx.doi.org/10.1021/bk-1989-0406.ch001

[7] Apparatus for Studying the Solubility of Substances Using Supercritical Fluids. Useful Model Patent RF No.133012 published on October 10, 2013.

[8] State Standard (GOST) 8136-85 Activated Alumina.

[9] Galimova, A.T., Sagdeev, A.A. and Gumerov, F.M. (2013) Izvestiya vyshih uchebnuh zavedeny. Seriya Khimiya i khimicheskaya tekhnologiya, 56, 65-68.

[10] Galimova, A.T., Sagdeev, A.A. and Gumerov, F.M. (2013) The Solubility of the Acetophenon and Methylphenylcarbinol in Supercritical Carbon Dioxide. Vestnik Kazanskogo Tekhnologicheskogo Universiteta, 16, 296-298.

[11] Sagdeev, K.A., Gallyamov, R.F., Sagdeev, A.A. and Gumerov, F.M. (2013) Regeneration of Palladium Selective Hydrogenation Catalyst by Supercritical Fluid Extraction Process. Vestnik Kazanskogo Tekhnologicheskogo Universiteta, 16, 20-23. 